\title{
Rare earth elements in the ornithogenic sediments from the Maritime Antarctic: A potential new palaeoecology proxy
}

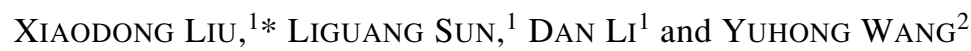 \\ ${ }^{1}$ Institute of Polar Environment, University of Science and Technology of China, Hefei, Anhui 230026, P.R. China \\ ${ }^{2}$ National Institutes of Health, Bethesda, MD 20892, U.S.A.
}

(Received November 23, 2008; Accepted May 6, 2010)

\begin{abstract}
The ornithogenic sediments in the maritime Antarctic are good archives for studying the changes of historical penguin population. Rare earth elements (REEs) along with biological and lithophile elements in two lacustrine sediment cores (Y2 and Y4) influenced by penguin droppings were analyzed with the aim of evaluating their potential as a new palaeoecological proxy. The relative concentrations of REEs in the two cores show dramatic changes, and the average REE contents are $71.21 \pm 11.56(n=37)$ and $37.18 \pm 10.64(n=18)$ for Y2 and Y4, respectively. The REE light/heavy content ratios $(\mathrm{L} / \mathrm{H})$ are $4.48 \pm 0.59$ for $\mathrm{Y} 2$ and $4.70 \pm 0.62$ for $\mathrm{Y} 4$, very close to the mean ratio of four pure guano samples. The chondrite-normalized REE patterns in the Y2 and Y4 sediments significantly influenced by penguin droppings are characteristic of more fractionation, obviously negative Ce anomalies and positive Er anomalies, likely imprinting the REE signal of guano input. The total REE concentration has a statistically significant negative correlation with the levels of guano-derived bio-elements and a positive correlation with the levels of Sc and Al mainly originated from weathered soils. The calculated proportion of guano-derived REE based on two-member mixing equation has a change pattern consistent with that of the historical penguin population size, previously reconstructed from bio-element concentrations in the sediments. These results suggest that the non-crustal signature of REE in the ornithogenic sediments may provide a new palaeoecological proxy for studying the palaeoecological processes of Antarctic penguins on a large time scale.
\end{abstract}

Keywords: Antarctica, ornithogenic sediments, rare earth elements, palaeoecology, penguin population

\section{INTRODUCTION}

In the studies on global changes, the eco-environmental history of polar region plays an important and indispensable role. The active history of sea animals such as penguins and seals in the ice-free areas of Antarctica is closely related to the advance and retreat of ice sheet, climatic change, sea level rise and decline, and marine productivity. It also provides abundant scientific information about the influence of climatic changes on Antarctic ecological system and the ecological response (Sun and Liu, 2007; Sun et al., 2006).

Abandoned penguin colonies are crucial for estimating historical penguin population and other palaeoenvironmental researches. In many coastal ice-free regions of Antarctica, the preserved organic remains in the ornithogenic soils at abandoned penguin colonies-such as penguin tissue (bone, feathers, dried skin, and eggshell) and prey remains (fish bone, otoliths, and squid beaks)-and their radiocarbon data can provide evidence

*Corresponding author (e-mail: ycx@ustc.edu.cn)

Copyright @ 2011 by The Geochemical Society of Japan. for past occupations by Adélie penguins (Baroni and Orombelli, 1994; Emslie, 2001; Emslie and McDaniel, 2002; Emslie et al., 1998, 2003; Emslie and Woehler, 2005). However, these older relics are generally not well preserved and difficult to be obtained. For example, the surface of old ornithologenic soils containing penguin remains can be entirely eroded and scoured by glacial advances, or dissolved in the wetter climatic zone of maritime Antarctica. The depositional sequences, well preserved in freshwater lake and influenced by sea animal excrements, have been utilized to reconstruct the historical population changes of Antarctic penguins and examine possible factors for their drastic changes (Sun et al., 2000, 2004, 2005, 2006; Sun and Xie, 2001; Liu et al., 2005a, 2006, 2007).

Rare earth elements (REEs), from Lanthanum to Lutetium, are a group of elements with similar chemical and physical properties due to their specific electronic configurations. Traditionally, REEs are divided into two subgroups: the light rare earth elements (LREEs) from La to $\mathrm{Eu}$, and the heavy rare earth elements (HREEs) from Gd to Lu (Henderson, 1984; Ravichandran, 1996). Because of the systematic variation of their behaviors due to the "lanthanide contraction", REEs have received considerable attention. For instance, REEs have been used to ex- 


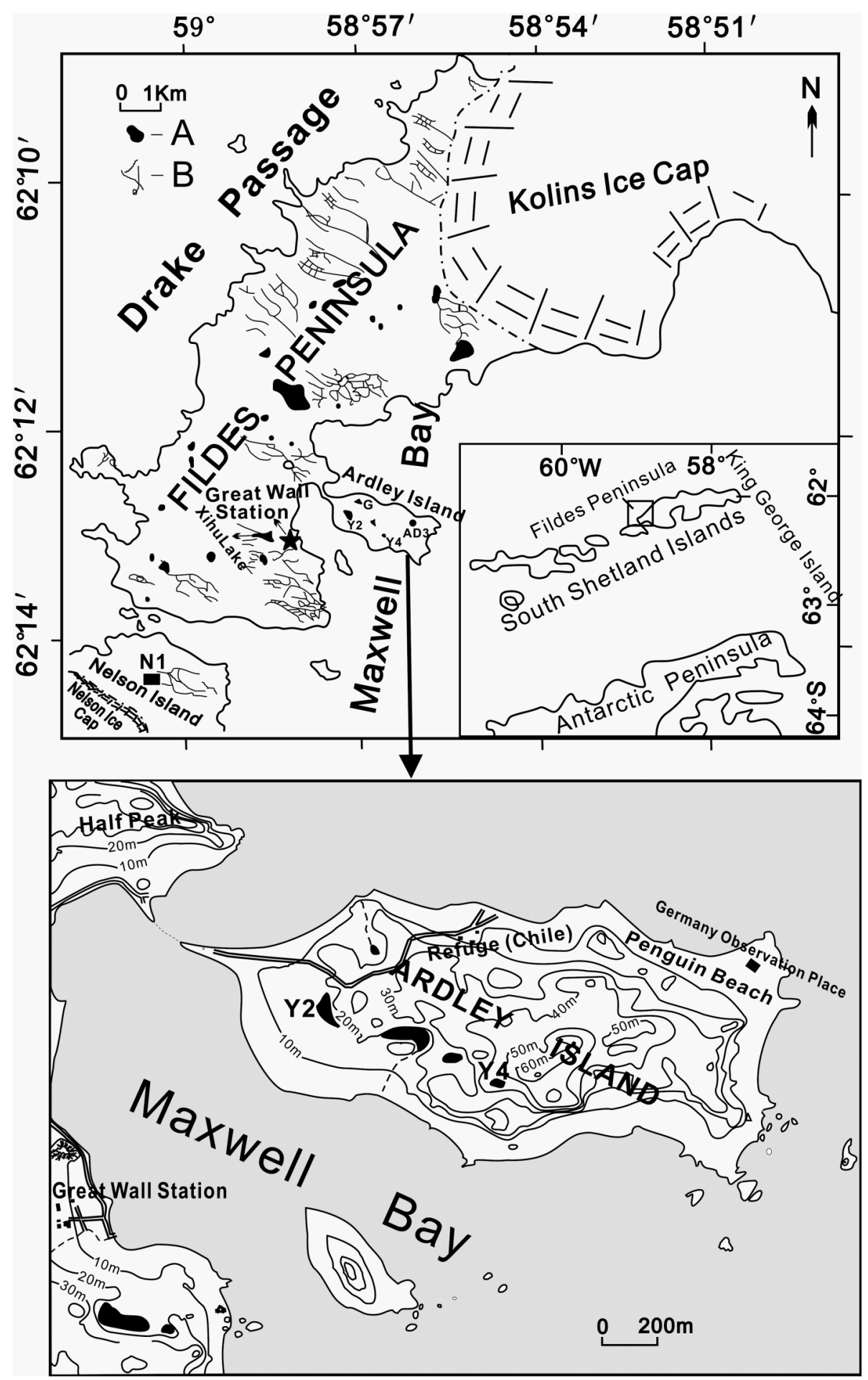

Fig. 1. Study area and sampling sites for the cores Y4 and Y2. In the top panel, marker A and B show lakes and network of meltwater channels, respectively. In the bottom panel, the contour interval is 10 meter.

plain many geochemical processes in the environment such as natural surface weathering processes, origin of some sediments, identification of anthropogenic impact, and palaeoenvironmental and palaeooceanic changes
(Olmez et al., 1991; Ravichandran, 1996; Bau and Dulski, 1996; Holser, 1997; Ramesh et al., 1999; Webb and Kamber, 2000; Nozaki et al., 2000; Yang et al., 2002; Lee et al., 2004; Shumilin et al., 2005; Caccia and Millero, 
2007; Tanaka et al., 2007; Piper et al., 2007). In this paper, we report for the first time the palaeoecological REE signal in the lacustrine sediments of the maritime Antarctic influenced by sea animal excrements, and examine the potential of REE distribution patterns and abundances as geochemical proxies for historical population of Antarctic penguins on a large time scale.

\section{STUDY AREA}

The Ardley Island $\left(62^{\circ} 13^{\prime} \mathrm{S}, 58^{\circ} 56^{\prime} \mathrm{W}\right)$, a $2 \mathrm{~km}$ long and $1.5 \mathrm{~km}$ wide island, is about $500 \mathrm{~m}$ east of Fildes Peninsula, Maxwell Bay, King George Island, and is connected to the Fildes Peninsula through a sandy dam (Fig. 1). The Great Wall Station of China is located about 0.5 $\mathrm{km}$ to the west. The study area has a cold oceanic climate, characteristic of maritime Antarctica. According to the meteorological records from the Great Wall Station, the mean annual precipitation is about $630 \mathrm{~mm}$, the annual average relative humidity is about $90 \%$, and the mean annual air temperature is around $-2.6^{\circ} \mathrm{C}$ with a winter low at $-26.6^{\circ} \mathrm{C}$ and a summer high at $11.7^{\circ} \mathrm{C}$. It is free of snow and ice during the summer. Geologically, this island mainly consists of tertiary andesitic and basaltic lavas and tuffs together with raised beach terraces. The topography of the island is relatively flat with the highest elevation of $70 \mathrm{~m}$. Seventy-eighty percent of the island is covered by vegetation, predominantly mosses and lichens.

Ardley Island is one of the most important penguin colonies in the maritime Antarctic region. In 1991, this island has been declared as Antarctic Specially Protected Area by the Protocol on Environmental Protection to the Antarctic Treaty. During the breeding period of every summer, the number of penguins on this island was around 10000, and the major species were Gentoo (Pygoscelis papua, 74\%), Adélie (Pygoscelis adeliae, 21\%) and Chinstrap (Pygoscelis antarctica, 5\%) (Trivelpiece et al., 1987). It is estimated that the penguins on the Ardley Island discharge about $139 \mathrm{t}$ droppings based on the hypothesis that each penguin excretes $84.5 \mathrm{~g}$ droppings (dry weight) a day during the breeding period. Droppings are transferred and deposited in the lakes or depressions by ice or snowmelt water, and these ancient penguin waste products could record historical information of penguin population change (Sun et al., 2000, 2001; Sun and Xie, 2001).

\section{Material AND Methods}

Fifty five samples from two sediment cores (37 for $\mathrm{Y} 2$ core and 18 for $\mathrm{Y} 4$ core) and 4 pure penguin guano samples were collected on the Ardley Island for concentration measurement of REEs. The Y2 and Y4 sediment cores, $67.5 \mathrm{~cm}$ and $34 \mathrm{~cm}$ long, were retrieved from Y2 and Y4 lakes using a $12 \mathrm{~cm}$-diameter PVC pipe during the austral summer of 1997/1998 and 1999/2000, respectively (Fig. 1). These two sediment cores were transported directly to the home laboratory without slicing, and were preserved in cold storage prior to being analyzed. In the laboratory, the sediment cores were sectioned at the intervals of 1-2 cm, and some subsamples discharges unpleasant smell, and a few ancient penguin bones, identified with reference to modern penguin bones from the Fildes Peninsula on the King George Island, are well preserved in these two cores (Liu et al., 2005a). According to the lithological observation and bio-element measurements, the amount of guanos in the top $4 \mathrm{~cm}$ sediment layer of Y4 core decreased significantly, and many plant remains appeared. For the Y2 sediment sequence, the sediments between 50 and $60 \mathrm{~cm}$ are predominantly composed of well-sorted and rounded fine sands with a small contribution of guanos. Except for these sediment layers mentioned above, the other sediment samples in both cores are significantly influenced by penguin droppings. The lithological descriptions of these two sediment cores have been previously reported in detail (Sun et al., 2000, 2001, 2004; Liu et al., 2005a).

For REE analysis, the subsamples were air-dried, sieved and then ground to powder $(<200$ mesh or 0.074 $\mathrm{mm}$ ), and then the powdered samples of $0.1 \mathrm{~g}$ were digested with $2 \mathrm{ml} \mathrm{HNO}_{3}, 1 \mathrm{ml} \mathrm{HCl}, 5-10 \mathrm{ml} \mathrm{HF}$ and 0.5 $\mathrm{ml} \mathrm{HClO}_{4}$ for $24 \mathrm{~h}$ in a tightly closed Teflon vessel and heated on a hotplate. The digests were evaporated to dryness at $300^{\circ} \mathrm{C}$ and extracted with $1 \mathrm{ml}$ pure $\mathrm{HCl}$ and small quantity of deionized water. After dissolution, the solution was placed into a $10 \mathrm{ml}$ colorimetric tube. REEs were measured by ICP-MS (Plasma Quad3, VG Elemental). Replicate measurements of samples, laboratory reagent blanks, and internal rock and sediment standards (GBW07104, GBW07604, GBW7120 and GBW07106) were used to control the analytical quality (Liu et al., $2005 \mathrm{~b}, 2008$ ). The relative standard deviation (RSD) of replicate analysis is generally less than 5\%, and the analyzed values lie within the certified ones of the standard samples.

We also analyzed the concentrations of $\mathrm{Zn}, \mathrm{Cu}, \mathrm{Ca}$, $\mathrm{Sr}, \mathrm{P}, \mathrm{Se}$ and $\mathrm{S}$ in the $\mathrm{Y} 2$ and $\mathrm{Y} 4$ lake sediment profiles. $\mathrm{Zn}, \mathrm{Cu}$ and $\mathrm{Ca}($ as $\mathrm{CaO})$ were determined by atomic absorption spectrometry (AAS); Sr by inductively coupled plasma atomic emission spectrometry (ICP-AES); P (as $\mathrm{P}_{2} \mathrm{O}_{5}$ ) by ultraviolet visible spectrometry (UVS); Se by atomic fluorescent spectrometry (AFS); and S by volume method (VOL) after fusion with KI. Concentration of Al in the sediments was determined by wet chemical method. These data have been published and the methods have been described by Sun et al. $(2000,2001,2004)$ and Liu et al. (2005a). The chronological control of Y2 and Y4 cores was based on conventional ${ }^{14} \mathrm{C}$ and radiometric dat- 
Table 1. Concentrations (

\begin{tabular}{|c|c|c|c|c|c|c|c|c|c|c|c|c|c|c|c|c|c|}
\hline Depth $[\mathrm{cm}]$ & $\mathrm{La}$ & $\mathrm{Ce}$ & $\operatorname{Pr}$ & $\mathrm{Nd}$ & $\mathrm{Sm}$ & $\mathrm{Eu}$ & $\mathrm{Gd}$ & $\mathrm{Tb}$ & Dy & Ho & $\mathrm{Er}$ & $\mathrm{Tm}$ & $\mathrm{Yb}$ & $\mathrm{Lu}$ & $\sum$ REE & LREE & HREE \\
\hline 0.5 & 9.22 & 24.23 & 2.88 & 14.57 & 3.37 & 1.14 & 3.68 & 0.57 & 3.48 & 0.72 & 2.82 & 0.28 & 1.68 & 0.38 & 69.02 & 55.41 & 13.61 \\
\hline 4.5 & 10.28 & 22.87 & 2.77 & 16.50 & 3.21 & 1.06 & 3.39 & 0.51 & 3.17 & 0.65 & 2.52 & 0.25 & 1.51 & 0.26 & 68.95 & 56.69 & 12.26 \\
\hline 8.5 & 12.40 & 23.09 & 5.65 & 14.78 & 2.86 & 0.95 & 3.38 & 0.47 & 2.84 & 0.57 & 2.21 & 0.23 & 1.36 & 0.24 & 71.02 & 59.73 & 11.29 \\
\hline 9.5 & 9.89 & 23.32 & 2.83 & 15.53 & 3.28 & 1.08 & 3.46 & 0.52 & 3.21 & 0.65 & 2.51 & 0.26 & 1.50 & 0.28 & 68.32 & 55.93 & 12.39 \\
\hline 11.5 & 12.12 & 19.62 & 4.98 & 16.79 & 3.81 & 1.27 & 4.25 & 0.62 & 3.79 & 0.77 & 2.96 & 0.30 & 1.78 & 0.33 & 73.40 & 58.59 & 14.80 \\
\hline 13.5 & 10.89 & 21.52 & 2.76 & 17.46 & 3.25 & 1.06 & 3.41 & 0.51 & 3.18 & 0.63 & 2.47 & 0.25 & 1.49 & 0.26 & 69.15 & 56.94 & 12.21 \\
\hline 14.5 & 10.22 & 22.38 & 3.11 & 15.69 & 3.69 & 1.22 & 3.86 & 0.58 & 3.59 & 0.73 & 2.81 & 0.29 & 1.70 & 0.30 & 70.17 & 56.31 & 13.86 \\
\hline 16.5 & 11.73 & 21.22 & 4.56 & 15.87 & 3.77 & 1.25 & 4.17 & 0.60 & 3.71 & 0.75 & 2.89 & 0.29 & 1.74 & 0.31 & 72.86 & 58.40 & 4.46 \\
\hline 18.5 & 12.31 & 21.35 & 4.64 & 16.87 & 3.73 & 1.23 & 4.16 & 0.61 & 3.67 & 0.75 & 2.88 & 0.29 & 1.72 & 0.31 & 74.52 & 60.13 & 14.39 \\
\hline 19.5 & 12.60 & 22.19 & 4.64 & 18.10 & 3.77 & 1.22 & 4.09 & 0.59 & 3.57 & 0.72 & 2.77 & 0.29 & 1.65 & 0.29 & 76.48 & 62.52 & 13.96 \\
\hline 21.5 & 12.24 & 21.77 & 4.58 & 17.22 & 3.89 & 1.29 & 4.32 & 0.62 & 3.78 & 0.76 & 2.96 & 0.30 & 1.76 & 0.32 & 75.82 & 60.99 & 4.83 \\
\hline 23.5 & 12.58 & 22.58 & 4.85 & 17.26 & 3.79 & 1.25 & 4.17 & 0.60 & 3.70 & 0.74 & 2.89 & 0.30 & 1.73 & 0.31 & 76.76 & 62.31 & 4.45 \\
\hline 24.5 & 12.11 & 25.78 & 5.44 & 15.65 & 3.57 & 1.15 & 4.08 & 0.58 & 3.56 & 0.71 & 2.73 & 0.28 & 1.65 & 0.28 & 77.56 & 63.70 & 3.87 \\
\hline 26.5 & 13.41 & 22.40 & 4.75 & 17.21 & 3.17 & 1.05 & 3.56 & 0.51 & 3.11 & 0.62 & 2.40 & 0.24 & 1.46 & 0.25 & 74.14 & 61.99 & 2.15 \\
\hline 28.5 & 10.79 & 20.25 & 4.01 & 14.69 & 3.28 & 1.05 & 3.52 & 0.51 & 3.03 & 0.61 & 2.45 & 0.24 & 1.49 & 0.26 & 66.18 & 54.07 & 12.12 \\
\hline 29.5 & 9.81 & 19.03 & 3.44 & 13.63 & 2.99 & 0.97 & 3.19 & 0.46 & 2.83 & 0.56 & 2.21 & 0.23 & 1.33 & 0.23 & 60.90 & 49.86 & 11.04 \\
\hline 31.5 & 10.66 & 22.55 & 3.42 & 17.67 & 4.16 & 1.35 & 4.56 & 0.71 & 4.45 & 0.90 & 3.54 & 0.37 & 2.17 & 0.37 & 76.87 & 59.80 & 17.07 \\
\hline 33.5 & 10.76 & 24.57 & 3.35 & 18.10 & 4.13 & 1.33 & 4.46 & 0.69 & 4.39 & 0.90 & 3.54 & 0.36 & 2.13 & 0.37 & 79.08 & 62.24 & 16.84 \\
\hline 34.5 & 10.44 & 23.53 & 3.15 & 16.91 & 3.82 & 1.25 & 4.12 & 0.64 & 4.03 & 0.82 & 3.22 & 0.33 & 1.95 & 0.34 & 74.54 & 59.10 & 15.44 \\
\hline 35.5 & 10.59 & 22.97 & 3.10 & 16.96 & 3.71 & 1.20 & 4.01 & 0.62 & 3.94 & 0.80 & 3.15 & 0.32 & 1.90 & 0.33 & 73.59 & 58.53 & 15.06 \\
\hline 36.5 & 8.14 & 23.09 & 2.44 & 12.63 & 2.88 & 0.94 & 2.98 & 0.46 & 2.82 & 0.58 & 2.23 & 0.23 & 1.35 & 0.23 & 60.99 & 50.12 & 10.87 \\
\hline 38.5 & 11.00 & 21.13 & 3.89 & 15.04 & 3.12 & 1.01 & 3.38 & 0.49 & 3.05 & 0.61 & 2.40 & 0.25 & 1.46 & 0.25 & 67.08 & 55.19 & 11.89 \\
\hline 39.5 & 9.86 & 22.76 & 2.86 & 15.69 & 3.43 & 1.11 & 3.64 & 0.56 & 3.51 & 0.72 & 2.81 & 0.29 & 1.73 & 0.29 & 69.27 & 55.71 & 13.56 \\
\hline 41.5 & 8.00 & 22.95 & 2.35 & 12.63 & 2.76 & 0.92 & 2.90 & 0.46 & 2.87 & 0.58 & 2.25 & 0.23 & 1.35 & 0.23 & 60.47 & 49.61 & 10.86 \\
\hline 43.5 & 12.65 & 22.45 & 5.28 & 16.03 & 3.27 & 1.08 & 3.72 & 0.53 & 3.29 & 0.66 & 2.60 & 0.26 & 1.56 & 0.27 & 73.64 & 60.75 & 12.89 \\
\hline 44.5 & 9.54 & 19.18 & 2.51 & 14.47 & 2.85 & 0.93 & 2.94 & 0.44 & 2.71 & 0.55 & 2.10 & 0.22 & 1.30 & 0.22 & 59.96 & 49.49 & 10.48 \\
\hline 46.5 & 9.97 & 20.83 & 2.49 & 15.66 & 2.96 & 0.96 & 3.07 & 0.47 & 2.87 & 0.58 & 2.27 & 0.23 & 1.39 & 0.24 & 63.99 & 52.87 & 11.12 \\
\hline 49.5 & 14.66 & 24.95 & 5.90 & 18.66 & 3.40 & 1.10 & 3.93 & 0.57 & 3.56 & 0.72 & 2.81 & 0.28 & 1.70 & 0.29 & 82.53 & 68.67 & 13.86 \\
\hline 50.5 & 11.76 & 25.40 & 4.16 & 17.22 & 3.36 & 1.10 & 3.91 & 0.57 & 3.54 & 0.72 & 2.87 & 0.29 & 1.74 & 0.30 & 76.93 & 62.99 & 13.94 \\
\hline 52.5 & 11.17 & 28.60 & 3.24 & 19.35 & 4.05 & 1.35 & 4.46 & 0.70 & 4.41 & 0.90 & 3.53 & 0.36 & 2.16 & 0.38 & 84.66 & 67.76 & 16.90 \\
\hline 54.5 & 10.54 & 29.04 & 3.02 & 17.92 & 3.75 & 1.24 & 4.07 & 0.65 & 4.03 & 0.82 & 3.20 & 0.34 & 1.96 & 0.33 & 80.89 & 65.51 & 15.39 \\
\hline 56.5 & 13.87 & 30.41 & 5.21 & 20.93 & 4.02 & 1.31 & 4.59 & 0.68 & 4.28 & 0.88 & 3.48 & 0.35 & 2.09 & 0.36 & 92.47 & 75.75 & 16.72 \\
\hline 58.5 & 15.13 & 29.70 & 6.57 & 21.09 & 4.14 & 1.37 & 4.80 & 0.71 & 4.45 & 0.91 & 3.54 & 0.36 & 2.13 & 0.37 & 95.25 & 77.99 & 17.26 \\
\hline 59.5 & 10.79 & 27.83 & 3.38 & 19.16 & 4.33 & 1.45 & 4.71 & 0.73 & 4.60 & 0.95 & 3.72 & 0.38 & 2.24 & 0.39 & 84.65 & 66.94 & 17.71 \\
\hline 61.5 & 8.64 & 18.15 & 2.97 & 11.91 & 2.44 & 0.80 & 2.66 & 0.38 & 2.34 & 0.48 & 1.89 & 0.19 & 1.14 & 0.20 & 54.19 & 44.91 & 9.28 \\
\hline 62.5 & 6.73 & 13.66 & 1.63 & 9.01 & 1.70 & 0.56 & 1.71 & 0.24 & 1.40 & 0.29 & 1.08 & 0.11 & 0.68 & 0.12 & 38.91 & 33.29 & 5.62 \\
\hline 63.5 & 7.85 & 12.87 & 2.61 & 8.98 & 1.62 & 0.51 & 1.65 & 0.22 & 1.29 & 0.25 & 0.99 & 0.10 & 0.61 & 0.11 & 39.65 & 34.44 & 5.22 \\
\hline
\end{tabular}

ing and reported in our previous publications (Sun et al., 2000; Liu et al., 2005a).

\section{RESULTS AND DISCUSSION}

Contents and patterns of REEs in ornithogenic sediments

The concentration means and ranges of REEs in the sediment cores $\mathrm{Y} 2$ and $\mathrm{Y} 4$ are summarized in Tables 1 and 2. For comparative purposes, the average REE concentrations in the guanos, Xihu lacustrine sediments without penguin dropping influence, marine sediments from the Great Wall Bay, and soils developed on basaltic andesite and lapilli tuff are also given in Table 3. As seen from these three tables, the concentrations of individual and total REE concentration ( $\Sigma$ REE) have large fluctuations. The average concentrations of total REE are 71.21 ppm (38.91-95.25 ppm, $n=37)$ and 37.18 ppm (28.34$68.34 \mathrm{ppm}, n=18$ ) for the $\mathrm{Y} 2$ and $\mathrm{Y} 4$ sediment cores, respectively. These values are remarkably lower than those in marine sediments, Xihu lacustrine sediments not influenced by penguin droppings, soils on basaltic andesite and lapilli tuff, but are significantly higher than those in guano samples. Nevertheless, the highest total REE concentrations (averaging $85.34 \mathrm{ppm}, n=7$ ) occur in the sediment samples from the depth of $50-60 \mathrm{~cm}$ of Y2 core, very close to those of the Xihu sediments that are not impacted by penguin droppings. Apparently, the remarkably lower REE concentrations in the ornithogenic sediments are related to the input of penguin droppings.

The sediment ratio of LREE (La to Eu) over HREE ( $\mathrm{Gd}$ to $\mathrm{Lu}$ ), i.e., $\mathrm{L} / \mathrm{H}$ ratio, is $4.48 \pm 0.59$ for $\mathrm{Y} 2$ core and $4.70 \pm 0.62$ for $\mathrm{Y} 4$ core; LREEs are more abundant than HREEs. The environmental media samples, as listed in Table 3, are greatly rich in LREE, apparently due to the fact that most shale and solid phases are relative more enriched in LREEs than in HREEs (Caccia and Millero, 2007). The $\mathrm{L} / \mathrm{H}$ ratios of the $\mathrm{Y} 2$ and $\mathrm{Y} 4$ ornithogenic sediments are higher than those of the lacustrine sediments 
Table 2. Concentrations ( $\mathrm{ppm}$ ) of rare earth elements in the sediment core $Y 4$

\begin{tabular}{|c|c|c|c|c|c|c|c|c|c|c|c|c|c|c|c|c|c|}
\hline Depth $[\mathrm{cm}]$ & $\mathrm{La}$ & $\mathrm{Ce}$ & $\mathrm{Pr}$ & $\mathrm{Nd}$ & $\mathrm{Sm}$ & $\mathrm{Eu}$ & $\mathrm{Gd}$ & $\mathrm{Tb}$ & Dy & Ho & $\mathrm{Er}$ & $\mathrm{Tm}$ & $\mathrm{Yb}$ & $\mathrm{Lu}$ & $\sum \mathrm{REE}$ & LREE & HREE \\
\hline 0.5 & 8.00 & 35.03 & 2.72 & 10.55 & 2.46 & 0.78 & 2.55 & 0.38 & 2.24 & 0.45 & 1.74 & 0.18 & 1.07 & 0.19 & 68.34 & 59.54 & 8.80 \\
\hline 1.5 & 7.96 & 23.77 & 2.52 & 11.10 & 2.62 & 0.84 & 2.66 & 0.40 & 2.38 & 0.48 & 1.88 & 0.19 & 1.16 & 0.20 & 58.16 & 48.81 & 9.35 \\
\hline 3.5 & 6.59 & 12.57 & 1.95 & 9.44 & 2.27 & 0.71 & 2.30 & 0.35 & 2.11 & 0.44 & 1.68 & 0.17 & 1.04 & 0.18 & 41.80 & 33.53 & 8.27 \\
\hline 5.5 & 6.10 & 11.49 & 1.78 & 8.61 & 2.04 & 0.65 & 2.06 & 0.30 & 1.80 & 0.37 & 1.43 & 0.15 & 0.86 & 0.15 & 37.79 & 30.67 & 7.12 \\
\hline 7.5 & 6.80 & 13.41 & 2.08 & 10.14 & 2.49 & 0.78 & 2.56 & 0.36 & 2.21 & 0.46 & 1.80 & 0.18 & 1.08 & 0.19 & 44.54 & 35.70 & 8.84 \\
\hline 9.5 & 6.35 & 12.28 & 1.92 & 9.32 & 2.24 & 0.71 & 2.32 & 0.36 & 2.26 & 0.46 & 1.82 & 0.20 & 1.07 & 0.19 & 41.50 & 32.82 & 8.68 \\
\hline 11.5 & 4.84 & 8.75 & 1.33 & 6.37 & 1.48 & 0.46 & 1.47 & 0.22 & 1.30 & 0.26 & 1.02 & 0.11 & 0.62 & 0.11 & 28.34 & 23.23 & 5.11 \\
\hline 13.5 & 5.30 & 9.73 & 1.49 & 7.18 & 1.68 & 0.53 & 1.67 & 0.25 & 1.49 & 0.30 & 1.17 & 0.12 & 0.71 & 0.12 & 31.74 & 25.91 & 5.83 \\
\hline 15.5 & 5.14 & 9.26 & 1.40 & 6.76 & 1.55 & 0.48 & 1.53 & 0.23 & 1.36 & 0.28 & 1.05 & 0.11 & 0.64 & 0.11 & 29.90 & 24.59 & 5.31 \\
\hline 17.5 & 5.53 & 10.08 & 1.53 & 7.34 & 1.70 & 0.54 & 1.67 & 0.26 & 1.53 & 0.30 & 1.19 & 0.12 & 0.71 & 0.12 & 32.62 & 26.72 & 5.90 \\
\hline 19.5 & 5.27 & 9.47 & 1.43 & 6.84 & 1.55 & 0.49 & 1.54 & 0.23 & 1.36 & 0.27 & 1.06 & 0.11 & 0.64 & 0.11 & 30.37 & 25.05 & 5.32 \\
\hline 21.5 & 5.46 & 9.81 & 1.47 & 7.12 & 1.66 & 0.51 & 1.61 & 0.24 & 1.40 & 0.28 & 1.09 & 0.12 & 0.65 & 0.12 & 31.54 & 26.03 & 5.51 \\
\hline 23.5 & 5.53 & 9.87 & 1.48 & 7.05 & 1.61 & 0.50 & 1.56 & 0.23 & 1.36 & 0.27 & 1.05 & 0.11 & 0.64 & 0.11 & 31.37 & 26.04 & 5.33 \\
\hline 25.5 & 5.56 & 10.04 & 1.51 & 7.29 & 1.65 & 0.52 & 1.63 & 0.24 & 1.41 & 0.28 & 1.09 & 0.11 & 0.65 & 0.11 & 32.09 & 26.57 & 5.52 \\
\hline 27.5 & 5.58 & 10.12 & 1.52 & 7.34 & 1.66 & 0.52 & 1.64 & 0.24 & 1.40 & 0.28 & 1.08 & 0.11 & 0.65 & 0.11 & 32.25 & 26.74 & 5.51 \\
\hline 29.5 & 5.64 & 10.21 & 1.54 & 7.41 & 1.67 & 0.53 & 1.66 & 0.24 & 1.42 & 0.28 & 1.11 & 0.12 & 0.68 & 0.12 & 32.63 & 27.00 & 5.63 \\
\hline 31.5 & 5.41 & 9.84 & 1.48 & 7.13 & 1.61 & 0.51 & 1.61 & 0.23 & 1.35 & 0.27 & 1.06 & 0.11 & 0.65 & 0.12 & 31.38 & 25.98 & 5.40 \\
\hline 33.5 & 5.67 & 10.31 & 1.54 & 7.47 & 1.70 & 0.54 & 1.70 & 0.25 & 1.44 & 0.29 & 1.14 & 0.12 & 0.69 & 0.12 & 32.98 & 27.23 & 5.75 \\
\hline
\end{tabular}

Table 3. Concentration mean and range (ppm) of REEs in the sediment cores Y2, Y4 and environmental media samples in the study area

\begin{tabular}{|c|c|c|c|c|c|c|c|c|c|}
\hline \multirow[t]{2}{*}{ Element } & \multicolumn{2}{|c|}{ Sediment core Y2 $(n=37)$} & \multicolumn{2}{|c|}{ Sediment core Y4 $(n=18)$} & \multicolumn{5}{|c|}{ Environmental medias } \\
\hline & Mean \pm SD & Range & Mean \pm SD & Range & Guano $^{\mathrm{a}}$ & $\mathrm{LS}^{\mathrm{b}}$ & $\mathrm{MS}^{\mathrm{c}}$ & Soil $(1)^{d}$ & Soil (2) \\
\hline $\mathrm{La}$ & $10.96 \pm 1.86$ & $6.73-15.13$ & $5.93 \pm 0.90$ & $4.84-8.00$ & 0.69 & 11.96 & 13.24 & 17.21 & 26.46 \\
\hline $\mathrm{Ce}$ & $22.71 \pm 3.70$ & $12.87-30.41$ & $12.56 \pm 6.54$ & $8.75-35.03$ & 0.96 & 23.32 & 27.51 & 38.66 & 61.37 \\
\hline $\operatorname{Pr}$ & $3.77 \pm 1.18$ & $1.63-6.57$ & $1.70 \pm 0.39$ & $1.33-2.72$ & 0.15 & 3.45 & 4.24 & 5.49 & 8.25 \\
\hline $\mathrm{Nd}$ & $16.05 \pm 2.68$ & $8.98-21.09$ & $8.03 \pm 1.45$ & $6.37-11.10$ & 0.70 & 18.23 & 16.60 & 27.78 & 42.21 \\
\hline $\mathrm{Sm}$ & $3.39 \pm 0.62$ & $1.62-4.33$ & $1.87 \pm 0.37$ & $1.48-2.62$ & 0.16 & 4.38 & 4.02 & 5.50 & 7.77 \\
\hline $\mathrm{Eu}$ & $1.11 \pm 0.21$ & $0.51-1.45$ & $0.59 \pm 0.12$ & $0.46-0.84$ & 0.05 & 1.60 & 1.18 & 1.75 & 2.12 \\
\hline Gd & $3.70 \pm 0.73$ & $1.65-4.8$ & $1.87 \pm 0.41$ & $1.47-2.66$ & 0.19 & 5.31 & 3.58 & 6.04 & 8.03 \\
\hline $\mathrm{Tb}$ & $0.55 \pm 0.12$ & $0.22-0.73$ & $0.28 \pm 0.06$ & $0.22-0.40$ & 0.02 & 0.84 & 0.60 & 0.85 & 1.05 \\
\hline Dy & $3.41 \pm 0.75$ & $1.29-4.60$ & $1.66 \pm 0.39$ & $1.30-2.38$ & 0.13 & 5.08 & 3.24 & 4.65 & 5.40 \\
\hline Ho & $0.69 \pm 0.16$ & $0.25-0.95$ & $0.33 \pm 0.08$ & $0.26-0.48$ & 0.03 & 1.07 & 0.67 & 0.93 & 1.04 \\
\hline $\mathrm{Er}$ & $2.69 \pm 0.16$ & $0.99-3.72$ & $1.30 \pm 0.32$ & $1.02-1.88$ & 0.11 & 2.88 & 1.84 & 2.68 & 3.03 \\
\hline $\mathrm{Tm}$ & $0.27 \pm 0.06$ & $0.10-0.38$ & $0.14 \pm 0.03$ & $0.11-0.20$ & 0.01 & 0.42 & 0.30 & 0.35 & 0.40 \\
\hline $\mathrm{Yb}$ & $1.63 \pm 0.37$ & $0.61-2.24$ & $0.79 \pm 0.20$ & $0.62-1.16$ & 0.07 & 2.57 & 1.89 & 2.39 & 2.73 \\
\hline $\mathrm{Lu}$ & $0.29 \pm 0.07$ & $0.11-0.39$ & $0.14 \pm 0.03$ & $0.11-0.20$ & 0.01 & 0.37 & 0.30 & 0.35 & 0.40 \\
\hline LREE & $57.98 \pm 8.97$ & 33.29-77.99 & $30.67 \pm 9.35$ & $23.23-59.54$ & 2.71 & 62.94 & 66.79 & 96.36 & 148.18 \\
\hline HREE & $13.23 \pm 2.84$ & $5.22-17.71$ & $6.51 \pm 1.53$ & $5.11-9.35$ & 0.57 & 18.54 & 12.42 & 18.23 & 22.08 \\
\hline $\mathrm{L} / \mathrm{H}$ & $4.48 \pm 0.59$ & $3.50-6.60$ & $4.70 \pm 0.62$ & $3.78-6.76$ & 4.73 & 3.39 & 5.38 & 5.29 & 6.71 \\
\hline$\sum \mathrm{REE}$ & $71.21 \pm 11.56$ & $38.91-95.25$ & $37.18 \pm 10.64$ & $28.34-68.34$ & 3.28 & 81.48 & 79.21 & 114.59 & 170.26 \\
\hline$\delta \mathrm{Ce}^{\mathrm{f}}$ & $0.85 \pm 0.18$ & $0.59-1.22$ & $0.88 \pm 0.24$ & $0.79-1.74$ & 0.67 & 0.84 & 0.85 & 0.92 & 0.96 \\
\hline$\delta \mathrm{Eu}^{\mathrm{f}}$ & $0.96 \pm 0.02$ & $0.92-1.00$ & $0.96 \pm 0.01$ & $0.95-0.98$ & 0.86 & 1.02 & 0.94 & 0.93 & 0.82 \\
\hline$(\mathrm{La} / \mathrm{Yb})_{\mathrm{CN}}$ & $4.60 \pm 1.04$ & $3.18-8.53$ & $5.07 \pm 0.57$ & $3.90-5.69$ & 6.70 & 3.06 & 4.62 & 4.74 & 6.38 \\
\hline
\end{tabular}

${ }^{a}$ The data for the pure guanos are the average values of 4 samples.

${ }^{b}$ The data for the Xihu lacustrine sediments are the average values of 18 samples from Xie et al. (2002) and Wang et al. (1996).

${ }^{c}$ The data for the marine sediments of Great Wall Bay are the average values of 15 samples from Wang (1991).

${ }^{d}$ The data for the soils on basaltic andesite of Barton Peninsula are the average of 18 samples from Lee et al. (2004).

${ }^{e}$ The data for the soils on Lapilli tuff of Barton Peninsula are the average of 4 samples from Lee et al. (2004).

${ }^{f} \delta C e=C e / C e^{*}=2 C e_{C N} /\left(L a_{C N}+P r_{C N}\right), \delta E u=E u / E u^{*}=2 E u_{C N} /\left(S m_{C N}+G d_{C N}\right)$, and CN stands for chondrite-normalized concentration. 

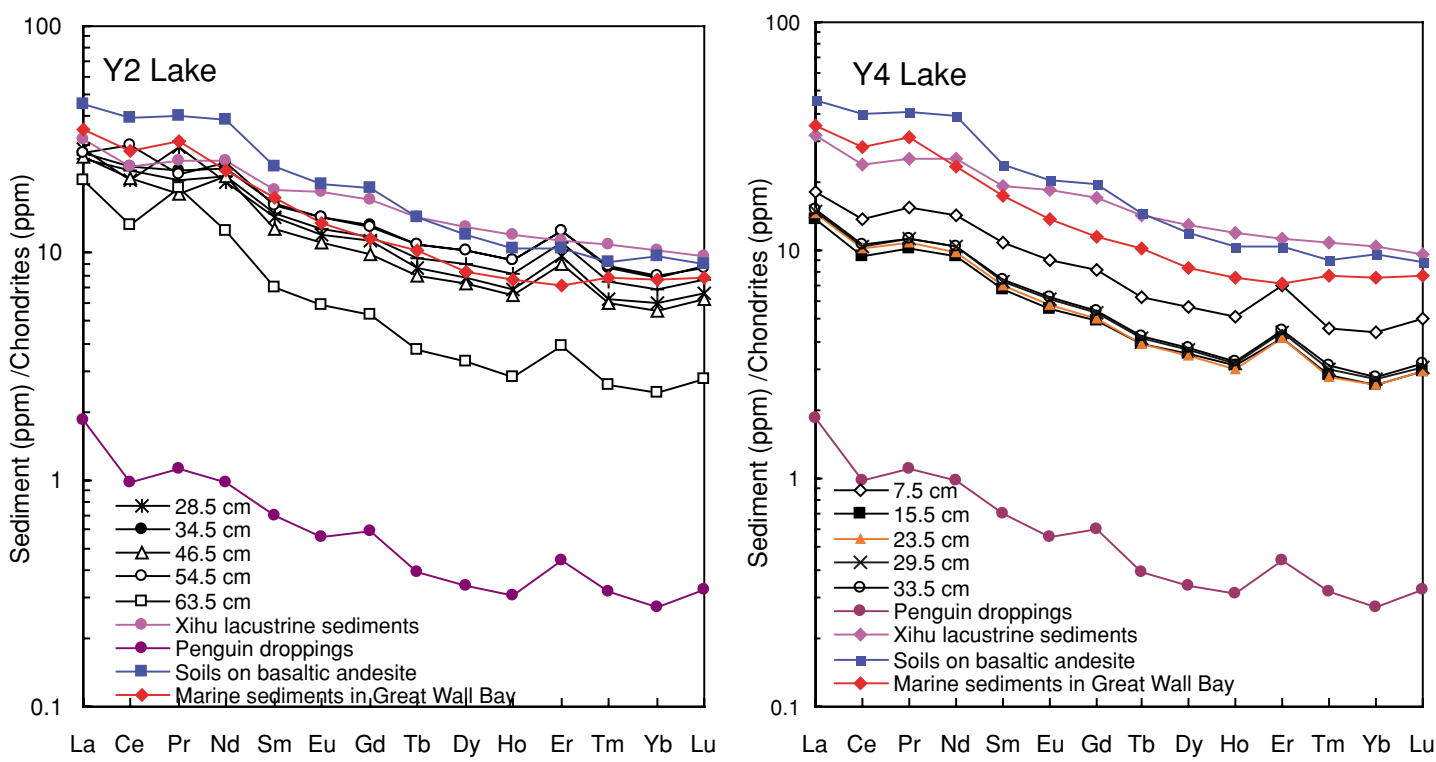

Fig. 2. Chondrite-normalized REE patterns for the Y2 and Y4 lacustrine sediments and environmental media samples. The chondrite values are cited from Masuda et al. (1973) and Masuda (1975).

without guano influence, lower than those of the marine sediments and weathered soils, and comparable to those of the guano samples. The input of penguin droppings into the lake sediments apparently exerts a significant influence on the concentrations and compositions of REEs in the ornithogenic sediments.

As indicated above, the relative abundances of REEs in different sediment samples are comparable even though the absolute levels of REEs may be greatly different. Therefore, it is a common practice to normalize the concentration of REEs to chondrite in order to identify characteristic sedimentary REE patterns (Caccia and Millero, 2007). Chondrite-normalized REE patterns for $Y 2$ and $Y 4$ ornithogenic sediments are illustrated in Fig. 2, together with those in the guanos, Xihu lacustrine sediments, marine sediments, and soils developed on basaltic andesite. As shown in Fig. 2, the chondrite-normalized distribution pattern of REEs in each sample of $\mathrm{Y} 2$ and $\mathrm{Y} 4$ sediment cores was generally similar to one another. Furthermore, the REE characteristics have no pronounced differences between Y2 and Y4 lacustrine sediments, indicating a common geochemical process of controlling REE distributions. The notable REE features in the Y2 and Y4 sediments are high abundances, relative to chondritic, light REE enrichment, and fairly flat heavy REE patterns. Ratio of $\mathrm{La}$ to $\mathrm{Yb}$ is often used to express a slope of REE pattern. Compared with the average value of $(\mathrm{La} / \mathrm{Yb})_{\mathrm{CN}}$ (CN: chondrite-normalized value) in the Xihu lacustrine sediments not influenced by penguin droppings, the Y2 and Y4 sediments are present relatively high values up to $4.60 \pm 1.04$ and $5.07 \pm 0.57$ respectively, reflecting stronger REE fractionation. The Xihu lake is very close to the Y2 and Y4 lakes (Fig. 1), and the geochemical characteristics of catchment bedrocks and weathered soils should have no significant difference. The obviously different degree of REE fractionation may be related to the guano input, since the penguin dropping has the highest $(\mathrm{La} / \mathrm{Yb})_{\mathrm{CN}}$ value, averaging $6.70(n=4)$ (Table 3). It also can be seen from Fig. 2 that the Y2 and Y4 sediment samples generally display obviously negative $\mathrm{Ce}$ and slightly negative Eu anomalies. Of all the environmental media samples such as Xihu lake sediments, guano, marine sediments and weathered soils, the guano sample has the most negative $\mathrm{Ce}$ anomaly with an average value of 0.67 . The elements in the penguin droppings are mainly derived from marine environment, and generally the sea water and some marine materials such as reefal microbialites show obviously negative Ce anomaly (Elderfield, 1988; Webb and Kamber, 2000). Also, the Ce anomaly in seawater varies with location and water depth. For example, the deep seawater generally has $\delta \mathrm{Ce}$ values (see the definition in Table 3 ) ranging from $<0.1-$ 0.4 (McMarthur and Walsh, 1984), but surface water generally has a small Ce anomaly (De Baar et al., 1985; Alibo and Nozaki, 1999). The guano-producing birds in the maritime Antarctic feed predominantly on fish and squid that live in relatively shallow seawater. Therefore, the moderately negative Ce anomaly in modern guano may reflect the characteristic of shallow sea water via natural food chain. As shown in Fig. 2, except for the sediment samples lacking the significant influence of penguin droppings such as $54.5 \mathrm{~cm}$ layer, most of the $\mathrm{Y} 2$ and $\mathrm{Y} 4$ 

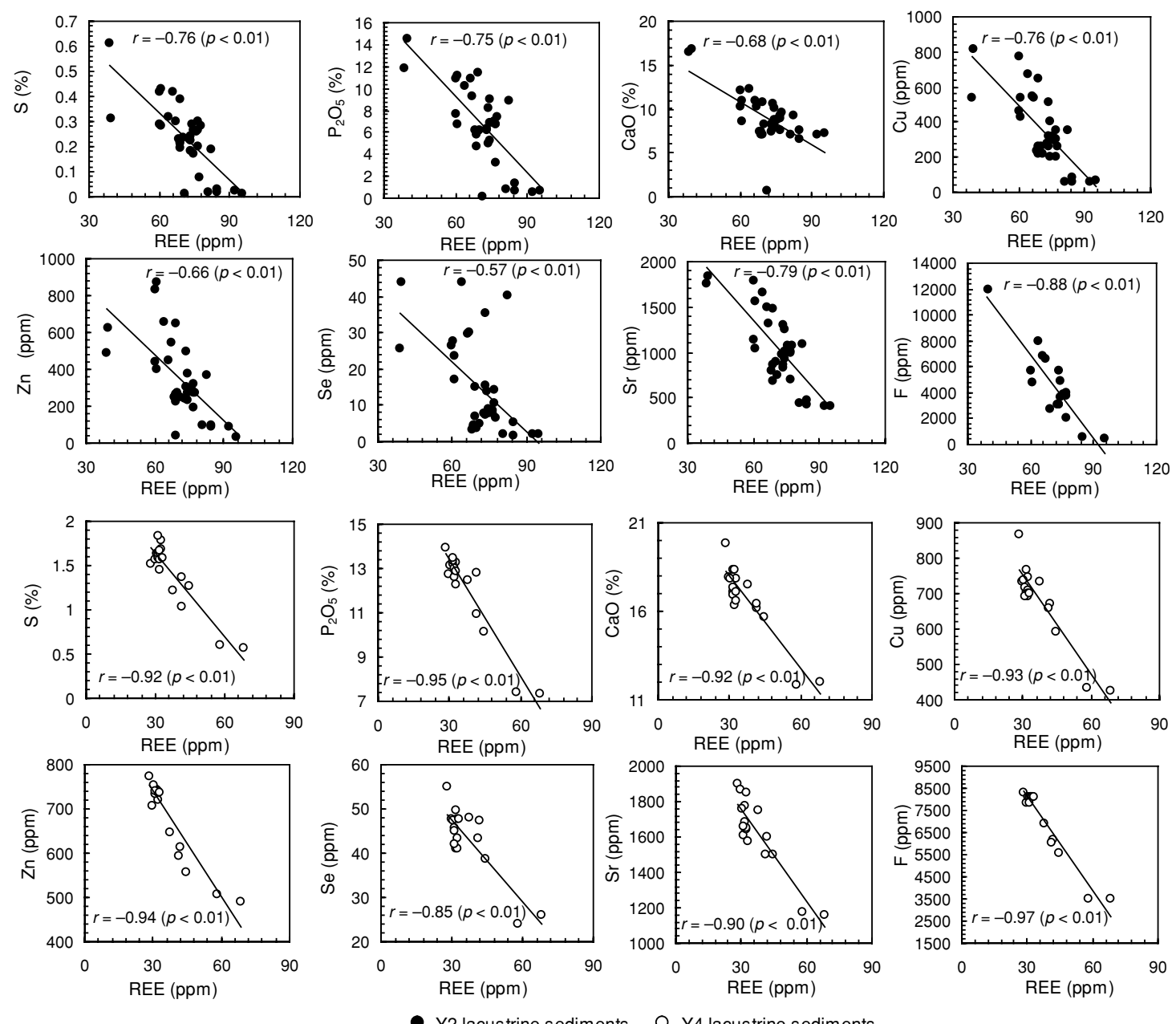

Fig. 3. Relationships between the contents of total REE and bio-elements in the ornithogenic sediment cores Y2 and Y4. Lines correspond to the best fit regression ones.

ornithogenic sediments generally have the negative $\mathrm{Ce}$ anomalies between the guanos and sediments, soils without guanos, probably indicating that the $\mathrm{Y} 2$ and $\mathrm{Y} 4$ ornithogenic sediments imprint the signal of negative $\mathrm{Ce}$ anomaly in the guanos. Very slightly negative Eu anomalies are observed in some ornithogenic sediments and Xihu lake sediments, suggesting that the guano input may not exert a significant impact on $\mathrm{Eu}$ anomalies in the ornithogenic sediments. Interestingly, most of the REE distribution patterns in the ornithogenic Y2 and Y4 sediments are characteristic of markedly positive $\mathrm{Er}$ anomalies, very similar to the modern guano samples (Fig. 2). However, these positive Er anomalies are not observed in the Xihu lacustrine sediments and soils without the influence of guanos, and the previous studies seldom report the Er anomalies. Recently, Wang et al. (2006) has used the Er anomalies in the aeolian sediments in the northeastern Tibetan Plateau area to identify their dust source. In the present paper, the exact cause of Er anomalies in the Antarctic ornithogenic sediments is not clear, but it may indicate the influence of penguin droppings or guano soils on the natural lake sediments in Antarctica. Generally, the ornithogenic sediments in the Y2 and Y4 lakes should show different Er anomalies, for example, the samples with high REE concentration should display relatively small Er anomalies due to the high contribution of soils with no Er anomaly. Nevertheless, all the ornithogenic samples seem to display obviously positive Er anomalies in Fig. 2. Here, we tentatively present an interpretation. Positive Er anomaly may be attributed to enrichment of Er. The guano is strongly rich in fluorapatite and organic matter, which may play an important role in the maintenance of relatively high concentrations of $\mathrm{Er}$ in the dissolved form by strong complexation with organic and inorganic ligands in solution. During mineral precipitation and contamination with guano materi- 

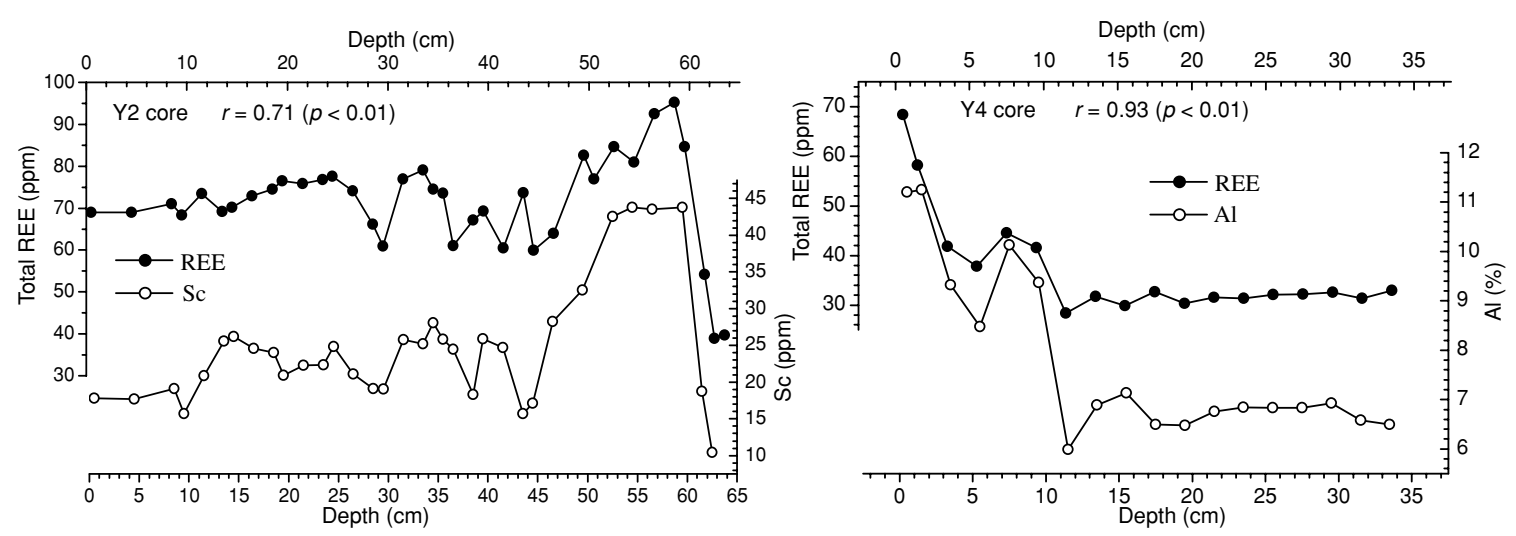

Fig. 4. Concentration versus depth profiles of total REE, Sc and Al in the Y2 and Y4 lacustrine sediments.

als, Er may be preferentially removed relative to Ho and Tm from dissolved water by particle scavenging. However, considering the few REE data reported previously in the seabird droppings and complex fractionation behaviour of REEs, we should discreetly use Er anomalies alone to identify the ornithogenic sediments, and much work is needed to understand such enrichment processes.

In summary, the chondrite-normalized REE patterns in the Y2 and Y4 ornithogenic sediments, characteristic of more fractionation, obviously negative $\mathrm{Ce}$ anomalies and significantly positive Er anomalies, likely record the REE signal of guanos. Moreover, as a whole, the chondrite-normalized REE patterns of the Y2 and Y4 sediments fall between those of sediments, soils without guano influence and the penguin droppings, further suggesting that the mixing process of guano and weathered soils is the main controlling factor for the REE patterns of the ornithogenic sediments. These characteristics of REE distribution patterns in the ornithogenic sediments have the potential of being a valuable tool to rapidly identify whether the sediments were influenced by penguin droppings in large scale Antarctic areas.

\section{Potential application of REEs for Antarctic penguin palaeoecology}

In order to further examine the factors controlling the REE abundances in the ornithogenic sediments and assess the potential of REE as a palaeoecological proxy, we analyzed the correlations between the contents of total REE and bio-elements in both sediment cores. Eight elements including $\mathrm{S}, \mathrm{P}\left(\mathrm{P}_{2} \mathrm{O}_{5}\right), \mathrm{CaO}, \mathrm{Cu}, \mathrm{Zn}, \mathrm{Se}, \mathrm{Sr}$ and $\mathrm{F}$ were identified as bio-elements for the $\mathrm{Y} 2$ and $\mathrm{Y} 4$ sediment cores (Sun et al., 2000, 2001, 2004; Liu et al., 2005a), and were enriched and significantly correlated with each other. Without remnants of penguin guanos these elements cannot be accumulated together since their chemical properties are very different. Therefore, the as- semblage of these eight elements is an important geochemical marker for penguin droppings or soils and sediments impacted by penguin droppings in the maritime Antarctic, and can be used as an indirect measure of historical penguin populations (Liu et al., 2005a). When the concentration of total REE in the ornithogenic sediments of $\mathrm{Y} 2$ and $\mathrm{Y} 4$ cores is plotted in binary plots as a function of the levels of the eight bio-elements (Fig. 3), statistically significant $(p<0.01)$ negative correlations were observed. Apparently, the input of penguin droppings is a main factor for the concentration of total REEs in the ornithogenic sediments. In contrast to bio-elements of $\mathrm{S}, \mathrm{P}, \mathrm{Ca}, \mathrm{Cu}, \mathrm{Zn}, \mathrm{Se}, \mathrm{Sr}$ and F, REEs are greatly depleted in the penguin droppings, and the total REE content is low down to $\sim 3 \mathrm{ppm}$ (Table 3 ).

The depth-concentration-profiles of total REE and lithological elements scandium ( $\mathrm{Sc}$ ) and aluminum (Al) in the Y2 and Y4 sediment cores are consistent with the negative correlation between total REE and bio-elements. Sc and Al are well-defined conservative lithophile elements, and their concentrations in the sediments are not significantly affected by biogenic cycles and anthropogenic contamination (Liu et al., 2005b). As shown in Fig. 4, the down-core trends of total REE, Sc and $\mathrm{Al}$ in the $\mathrm{Y} 2$ and $\mathrm{Y} 4$ cores are very similar, and the total REE is significantly correlated with $\mathrm{Sc}$ in $\mathrm{Y} 2$ and $\mathrm{Al}$ in $\mathrm{Y} 4$ with correlation coefficients of 0.71 and $0.93(p<0.01)$, respectively.

The levels of bio-elements in the ornithogenic sediments indicate the contribution from penguin droppings, and the levels of $\mathrm{Sc}$ and $\mathrm{Al}$ indicate the input of weathered soil to the lakes. The strong associations between REEs, bio-elements and Sc and Al suggest that the REE abundances in the ornithogenic sediments are derived from penguin guano as well as local bedrock and weathered material around the catchment. Nevertheless, one may suspect that the total concentrations of these 


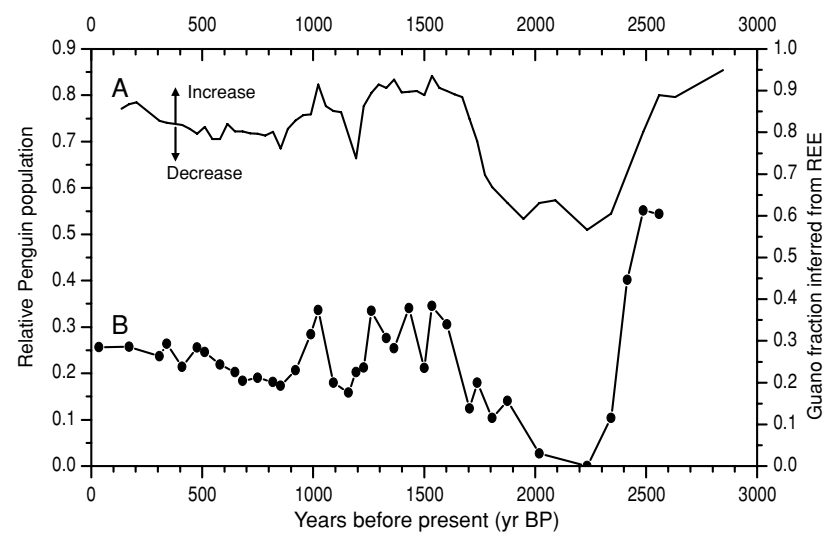

Fig. 5. Palaeoecological significance of REE in the Y2 sediment core. Curve A is historical penguin populations during the past 3,000 years deduced from the change of penguin droppings in the sediments based on the determination of nine bioelements (Sun et al., 2000); Curve B is the guano fraction inferred from the change of total REE concentration in the sediments. The correlation coefficient between curves $A$ and $B$ is $0.67(r<0.001)$.

REEs may be related to the erosive rate of overland runoff. For example, the periods of warmer climate would increase overland runoff and inwash into lake due to high precipitation and strong chemical weathering etc., resulting in the elevation of REE concentrations in the sediments. The relative proportions of penguin droppings and lithological materials in the overland runoff, however, are expected to be stable. The increase of the overland runoff would lead to the rise of the amount of lithogenic material, simultaneously, the amount of penguin dropping input into lakes is also increased, and thus the changes of inorganic element concentrations in the ornithogenic sediments are expected to be related to the fluctuation of seabird population, not the erosive rate. This finding is affirmed by our previous works on the bioelement analysis (Sun et al., 2000; Liu et al., 2007). The REE concentrations in the sediments are mainly controlled by the relative amount of penguin guanos and weathering products from local bedrock, therefore, a simple two-member mixing equation could be used to estimate relative contributions of penguin droppings and weathered soils in the total REE composition of the bulk ornithogenic sediments. One can estimate the proportion of penguin droppings in the ornithogenic sediments based on a mass balance calculation (Elsenbeer et al., 1995; Xue et al., 2009):

$$
\begin{gathered}
\mathrm{REE}_{\text {sample }}=f \mathrm{REE}_{\text {guano }}+(1-f) \mathrm{REE}_{\text {weathering }} \\
f=\left[(\mathrm{REE})_{\text {sample }}-(\mathrm{REE})_{\text {weathering }}\right] \\
\quad /\left[(\mathrm{REE})_{\text {guano }}-(\mathrm{REE})_{\text {weathering }}\right] .
\end{gathered}
$$

Where $\mathrm{REE}_{\text {sample }}$ is the determined REE content in the ornithogenic sediments; $\mathrm{REE}_{\text {weathering }}$ and $\mathrm{REE}_{\text {guano }}$ are the REE contents in the weathering-derived and guanoderived sources, respectively; $f$ is the guano-derived fraction in the sample. Here, we selected sediment core Y2 as an example to calculate the relative proportion of guano-derived REE. We used the sediment sample with the highest REE content (95.25 ppm at $58.5 \mathrm{~cm}$ depth) and the mean value of four guano samples as representations of local weathering-derived and guano-derived sources, respectively. The calculated relative contribution versus age profile of REE from the penguin guano in the Y2 lake sediments is given in Fig. 5. The profile is consistent with the reconstructed penguin population change versus age based on the analysis of bio-elements in the ornithogenic sediments. The penguin population began to decline around 3,000 $\mathrm{yr}$ before present (yr B.P.) and was lowest at 1,800-2,300 yr B.P., corresponding to Neoglacial period. After that, the population increased and peaked between 1,400-1,800 yr B.P., corresponding to a time period of warm climate (Sun et al., 2000).

Penguin relics preserved in lake sediments have been successfully used to detect the presence, absence and possibly broad scale changes of historical penguin populations (Sun et al., 2000, 2006). As shown above, the total REE and the bio-element contents of the ornithogenic sediment cores $\mathrm{Y} 2$ and $\mathrm{Y} 4$ have negative and statistically significant bivariate correlations, and the profile of relative guano input contribution inferred from total REEs is almost consistent with the historical change of penguin population. In order to further verify individual REE composition as potential palaeoecological proxy, using the above two end-member mixture model, we have calculated the relative contributions of penguin guano to the sediments based on each REE concentration, and then performed the Pearson correlation analysis between the changes of each guano-derived fraction and the historical penguin population. The results showed that the calculated guano proportions inferred from most REE had significantly positive correlations with penguin population at the level of 0.01 (their correlation coefficients $\sim 0.6$, $p<0.01$ ), with the exception of $\operatorname{Pr}$ showing significant correlation at the level of 0.05 . Therefore, we propose that the concentrations of each REE and total REE in the ornithogenic lacustrine sediments have a good potential of being used as new markers and palaeoecological proxies for historical penguin population changes in the Antarctic region.

In summary, we suggested that the distribution patterns of REEs could provide a rapid and valuable technique to indirectly identify whether the sediments were influenced by penguin droppings in the Antarctic region. Combined with the changes of absolute REE concentrations, it is likely to reconstruct historical record of pen- 
guin populations occupied around the lake catchment. The concentrations of $\mathrm{Cu}, \mathrm{S}, \mathrm{Sr}, \mathrm{Zn}, \mathrm{P}, \mathrm{Ca}, \mathrm{Ba}, \mathrm{F}$ and $\mathrm{Se}$ in the sediments impacted by penguin guano have successfully been used as the proxy for the size of historical penguin populations (Sun et al., 2000, 2004; Sun and Xie, 2001; Zhu et al., 2005; Liu et al., 2005a, 2007). However, the analytical methods of these inorganic elements are different due to the significant differences of their chemical properties, and thus the concentration measurements in sediments are usually time-consuming in the laboratory. Comparing with the traditional element analysis, there are a few advantages for using REEs. Firstly, the REEs have low solubility and mobility and are unlikely to partition during most geologic processes and after deposition; Secondly, REEs have minimal anthropogenic use (Chiarenzelli et al., 2001); and thirdly use of an unusually coherent group of elements (Lanthanide Series), with similar geochemical properties and simultaneous analytical technique, minimizes analytical and other sources of error, yields robust concentrations ( $\mathrm{ppm}$ ) in the ornithogenic sediments and guano samples, and provides a multi-component pattern or fingerprint highly sensitive to the guano input into the lake due to the significantly lower REE contents in penguin droppings relative to the weathered soils (Banks et al., 1999; Chiarenzelli et al., 2001). In addition, because of the drastically different REE patterns and concentrations in the lake sediments with and without penguin droppings, monitoring the REEs in lake sediment samples should provide a useful check on the degree of guano contamination in a given sample. Finally, as the complementary method of bio-elements, the use of REEs as tracers in penguin palaeoecological reconstruction provides a unique database for comparative purposes in Antarctic eco-environmental studies.

\section{Conclusions}

We analyzed REEs in two lacustrine sediment cores Y2 and Y4 on the Ardley Island of Antarctic King George Island, and examined the potential of REE as a new palaeoecological proxy. The REE levels in the ornithogenic sediments show large variation. They are generally lower than those of weathered soils, lacustrine sediments without guano effect and marine sediments, but higher than those of pure guanos. All the ornithogenic sediments have the mean ratio of LREE/HREE close to that of guanos, but different from those of other environmental medium samples not influenced by guanos. The chondrite-normalized REE patterns in both sediment cores are similar, and all the REE patterns vary between the sediments and soils without guano impact and the pure guano. Total REE showed a positive correlation with lithophile elements $\mathrm{Al}$ and $\mathrm{Sc}$, and a negative correlation with the guano-derived bio-elements. The REE abun- dances and compositions in the ornithogenic sediments can be explained by mixing of guanos and weathered soils. The REE contributions from penguin droppings as calculated from two-member mixing equation have change profiles similar to those of the historical penguin population size as estimated from bio-element concentrations in the sediments. These results suggest that the REE patterns and abundances in the ornithogenic sediments, like bio-elements, can potentially be used as an indirect and new proxy for the historical population size of penguins in the maritime Antarctic.

Acknowledgments-We would like to thank Polar Office of National Oceanic Bureau of China for support and assistance. This study was supported by the National Natural Science Foundation (Grant Nos. 40876096, 41076123, 40606003 and 40730107), the young fund for strategetic research of Chinese polar sciences from CAAA (No. 20070202), open research fund from SOA Key Laboratory for Polar Science (KP2007002) and special fund for excellent Ph.D. Thesis of CAS. We especially appreciate three anonymous reviewers for their critical reviews and careful corrections on this manuscript.

\section{REFERENCES}

Alibo, D. S. and Nozaki, Y. (1999) Rare earth elements in seawater: particle association, shale-normalization, and $\mathrm{Ce}$ oxidation. Geochim. Cosmochim. Acta 63, 363-372.

Banks, D., Hall, G., Reimann, C. and Siewers, U. (1999) Distribution of rare earth elements in crystalline bedrock of groundwaters: Oslo and Bergen regions, Norway. Appl. Geochem. 14, 27-39.

Baroni, C. and Orombelli, G. (1994) Abandoned penguin rookeries as Holocene paleoclimatic indicators in Antarctica. Geology 22, 23-26.

Bau, M. and Dulski, P. (1996) Anthropogenic origin of positive gadolinium anomalies in river waters. Earth Planet. Sci. Lett. 143, 245-255.

Caccia, V. G. and Millero, F. J. (2007) Distribution of yttrium and rare earths in Florida Bay sediments. Mar. Chem. 104, $171-185$.

Chiarenzelli, J., Aspler, L., Dunn, C., Cousens, B., Ozarko, D. and Powis, K. (2001) Multi-element and rare earth element composition of lichens, mosses, and vascular plants from the Central Barrenlands, Nunavut, Canada. Appl. Geochem. 16, 245-270.

De Baar, H. J. W., Bacon, M. P., Brewer, P. G. and Bruland, K. W. (1985) Rare earth elements in the Pacific and Atlantic Oceans. Geochim. Cosmochim. Acta 49, 1943-1959.

Elderfield, H. (1988) The oceanic chemistry of the rare-earth elements. Philos. Trans. R. Soc. London Ser. A 325, 105126.

Elsenbeer, H., Lorieri, D. and Bonell, M. (1995) Mixing model approaches to estimate storm flow sources in an overland flow-dominated tropical rain forest catchment. Water Resour. Res. 31, 2267-2278.

Emslie, S. D. (2001) Radiocarbon dates from abandoned pen- 
guin colonies in the Antarctica Peninsula region. Antarct. Sci. 13, 289-295.

Emslie, S. D. and McDaniel, J. D. (2002) Adélie penguin diet and climate change during the middle to late Holocene in northern Marguerite Bay, Antarctic Peninsula. Polar Biol. 25, 222-229.

Emslie, S. D. and Woehler, E. J. (2005) A 9000-year record of Adélie penguin occupation and diet in the Windmill Islands, East Antarctica. Antarct. Sci. 17, 57-66.

Emslie, S. D., Fraser, W. R., Smith, R. C. and Walker, W. (1998) Abandoned penguin colonies and environmental change in the Palmer Station areas, Anvers Island, Antarctic Peninsula. Antarct. Sci. 3, 257-268.

Emslie, S. D., Berkman, P. A., Ainley, D. G., Coats, L. and Polito, M. (2003) Late-Holocene initiation of ice-free ecosystems in the southern Ross Sea, Antarctica. Mar. Ecol.Prog. Ser. 262, 19-25.

Henderson, P. (1984) General geochemical properties and abundances of the rare earth elements. Rare Earth Element Geochemistry (Henderson, P., ed.), 1-32, Elsevier, New York.

Holser, W. T. (1997) Evaluation of the application of rare-earth elements to paleoceanography. Palaeogeogr. Palaeoclimatol. Palaeoecol. 132, 309-323.

Lee, Y. I., Lim, H. S. and Yoon, H. I. (2004) Geochemistry of soils of King George Island, South Shetland Islands, West Antarctica: Implications for pedogenesis in cold polar regions. Geochim. Cosmochim. Acta 68, 4319-4333.

Liu, X. D., Sun, L. G., Xie, Z. Q., Yin, X. B. and Wang, Y. H. (2005a) A 1300-year record of penguin populations at Ardley Island in the Antarctica, as deduced from the geochemical data in the ornithogenic lake sediments. Arct. Antarct. Alp. Res. 37, 490-498.

Liu, X. D., Sun, L. G., Yin, X. B., Zhu, R. B., Xie, Z. Q. and Wang, Y. H. (2005b) A preliminary study of elemental geochemistry and its potential application in Antarctic seal palaeoecology. Geochem. J. 39, 47-59.

Liu, X. D., Li, H. C., Sun, L. G., Yin, X. B., Zhao, S. P. and Wang, Y. H. (2006) $\delta^{13} \mathrm{C}$ and $\delta^{15} \mathrm{~N}$ in the ornithogenic sediments from the Antarctic maritime as paleoecological proxies during the past 2000 years. Earth Planet. Sci. Lett. 243, 424-438.

Liu, X. D., Sun, L. G., Xie, Z. Q., Yin, X. B., Zhu, R. B. and Wang, Y. H. (2007) Preliminary geochemical record for the pre-historical seabird population in "Mochou" Lake sediments on the Larseman Hills, East Antarctica. Boreas 36, 182-197.

Liu, X. D., Sun, L. G., Cheng, Z. Q., Zhao, S. P., Liu, K. X., Wu, X. H., Xie, Z. Q., Yin, X. B., Luo, H. H., Ding, X. F., Fu, D. B. and Wang, Y. H. (2008) Paleoenvironmental implications of the guano phosphatic cementation on Dongdao Island in the South China Sea. Mar. Geol. 247, 1-16.

Masuda, A. (1975) Abundances of monoisotopic REE, consistent with Leedey chondrite values. Geochem. J. 9, 183-184.

Masuda, A., Nakamura, N. and Tanaka, T. (1973) Fine structures of mutually normalized rare-earth patterns of chondrites. Geochim. Cosmochim. Acta 37, 239-248.

McMarthur, J. M. and Walsh, J. N. (1984) Rare-earth geochemistry of phosphorites. Chem. Geol. 47, 191-220.
Nozaki, Y., Lerche, D., Alibo, D. S. and Tsutsumi, M. (2000) Dissolved indium and rare earth elements in three Japanese rivers and Tokyo Bay: Evidence for anthropogenic Gd and In. Geochim. Cosmochim. Acta 64, 3975-3982.

Olmez, I., Sholkovitz, E. R., Hermann, D. and Eganhouse, R. P. (1991) Rare earth elements in sediments of southern California: a new anthropogenic indicator. Environ. Sci. Technol. 25, 310-316.

Piper, D. Z., Perkins, R. B. and Rowe, H. D. (2007) Rare-earth elements in the Permian Phosphoric Formation: paleo proxies of ocean geochemistry. Deep-Sea Res. Part II 54, 13961413.

Ramesh, R., Ramanathan, A. L., James, R. A., Subramanian, V., Jacobsen, S. B. and Holland, H. D. (1999) Rare earth elements and heavy metal distribution in estuarine sediments of east coast of India. Hydrobiologia 397, 89-99.

Ravichandran, M. (1996) Distribution of Rare Earth Elements in Sediment Cores of Sabine-Neches Estuary. Mar. Pollut. Bull. 32, 719-726.

Shumilin, E., Rodríguez-Figueroa, G. and Sapozhnikov, D. (2005) Lanthanide contamination and strong positive europium anomalies in the surface sediments of the Santa Rosalía copper mining region, Baja California Peninsula, Mexico. Bull. Environ. Contam. Toxicol. 75, 308-315.

Sun, L. G. and Liu, X. D. (2007) Eco-environmental change records of Antarctic ice-free areas in the sediments influenced by marine animals. Adv. Clim. Change Res. 3 (Suppl.), 35-40.

Sun, L. G. and Xie, Z. Q. (2001) Relics: penguin population programs. Sci. Prog. 84, 31-44.

Sun, L. G., Xie, Z. Q. and Zhao, J. L. (2000) A 3,000-year record of penguin populations. Nature $\mathbf{4 0 7}, 858$.

Sun, L. G., Xie, Z. Q. and Zhao, J. L. (2001) The sediments of lake on the Ardley Island, Antarctic: identification of penguin-dropping soil. Chinese J. of Polar Sci. 12(1), 1-8.

Sun, L. G., Zhu, R. B., Yin, X. B., Liu, X. D., Xie, Z. Q. and Wang, Y. H. (2004) A geochemical method for reconstruction of the occupation history of penguin colony in the maritime Antarctic. Polar Biol. 27, 670-678.

Sun, L. G., Zhu, R. B., Liu, X. D., Xie, Z. Q., Yin, X. B., Zhao, S. P. and Wang, Y. H. (2005) HCl-soluble ${ }^{87} \mathrm{Sr} /{ }^{86} \mathrm{Sr}$ ratio in the sediments impacted by penguin or seal excreta as a proxy for the size of historical population in the maritime Antarctic. Mar. Ecol.-Prog. Ser. 303, 43-50.

Sun, L. G., Xie, Z. Q., Liu, X. D., Yin, X. B. and Zhu, R. B. (2006) Eco-Geology in Antarctic Ice-Free Areas. Science Press, P.R. China, 306 pp. (in Chinese).

Tanaka, K., Akagawa, F., Yamamoto, K., Tani, Y., Kawabe, I. and Kawai, T. (2007) Rare earth element geochemistry of Lake Baikal sediment: its implication for geochemical response to climate change during the Last Glacial/Interglacial transition. Quaternary Sci. Rev. 26, 1362-1368.

Trivelpiece, W. Z., Trivelpiece, S. G. and Volkman, N. J. (1987) Ecological segregation of Adélie, Gentoo, and Chinstrap penguins at King George Island, Antarctica. Ecology 68, 351-361.

Wang, X. L. (1991) A preliminary study on REE in the sediments of the Great Wall Bay, Antarctica. Antarct. Res. 3(3), 3944 (in Chinese with English abstract). 
Wang, X. Y., Lu, H. Y., Ji, J. F., Wang, X. Y., Zhao, J. B., Huang, B. C. and Li, Z. (2006) Origin of the Red Earth sequence on the northeastern Tibetan Plateau and its implications for regional aridity since the middle Miocene. Science in China: Series D. 49(5), 505-517.

Wang, Y. X., Qian, Z. X. and Zheng, H. H. (1996) REE geochemistry of lacustrine deposit on the Fildes Peninsula. Antarct. Res. 8(2), 35-41 (in Chinese with English abstract).

Webb, G. E. and Kamber, B. S. (2000) Rare earth elements in Holocene reefal microbialites: a new shallow seawater proxy. Geochim. Cosmochim. Acta 64, 1557-1565.

Xie, Z. Q., Sun, L. G., Liu, X. D. and Zhao, J. L. (2002) The Characteristic of $1 / \delta$ Eu in the Sediments of West Lake with respect to climate change during the past 2000 years, Fildes
Peninsula, Antarctic. Acta Sedimentologica Sinica 20(2), 303-306 (in Chinese with English abstract).

Xue, B., Yan, C. L., Lu, H. L. and Bai, Y. (2009) MangroveDerived Organic Carbon in Sediment from Zhangjiang Estuary (China) Mangrove Wetland. J. Coastal Res. 25, 949956.

Yang, S. Y., Jung, H. S., Choi, M. S. and Li, C. X. (2002) The rare earth element compositions of the Changjiang (Yangtze) and Huanghe (Yellow) river sediments. Earth Planet. Sci. Lett. 201, 407-419.

Zhu, R. B., Sun, L. G., Yin, X. B., Xie, Z. Q. and Liu, X. D. (2005) Geochemical evidence for rapid enlargement of gentoo penguin colony on Barton Peninsula in the Maritime Antarctic. Antarct. Sci., 17, 11-16. 